I. ROZPRAWY I ANALIZY

Jadwiga $\mathrm{P}$ u z y n i n a

(Warszawa)

\title{
KŁOPOTY Z NAZWAMI WARTOŚCI (I WARTOŚCIAMI)
}

Autorka omawia trudności, jakie sprawia rozumienie języka wartości i posługiwanie się nim w komunikacji: rozumienie samego terminu wartość, a także licznych nazw wartości o ogólnych znaczeniach oraz wielu składowych cechach semantycznych. Problem ten jest omawiany szerzej na przykładzie różnych indywidualnych interpretacji przymiotnika dobry jako określenia człowieka. Do kłopotów z samymi wartościami, ale także z ich nazwami, należą też częste w życiu wielu ludzi zmiany ich indywidualnych hierarchii wartości. Wszystkie te problemy prowadzą do poważnych zakłóceń w komunikacji i do niewłaściwości w ocenach.

W końcowej części artykułu autorka zajmuje się też problemem sposobów wpływania na etycznie racjonalne - ważne dla celów społecznych i ogólnie humanistycznych - kształtowanie tożsamości młodego pokolenia.

SŁowA KLUCzowe: język wartości, nazwy wartości, komunikacja, tożsamość, dobry

Tezą, która stanowi punkt wyjścia tego artykułu, jest przekonanie o ważności języka wartości dla sposobu i jakości życia jednostek i społeczności. Ważne są przede wszystkim same wartości, które docierają do nas jako treści wyrażeń należących do tego języka - mówią one o tym, co uważamy za dobre, a co za złe. Ważny jest i sam język - narzędzie nie tylko komunikacji, ale i myślenia.

Kłopoty, jakie rodzą się w związku z językiem wartości, są różnorodne. Pierwszym z nich jest rozumienie samego kluczowego pojęcia wartości. W przeszłości dobro i zło utożsamiano z transcendentaliami, do dziś część filozofów pojęcie wartości także ogranicza do transcendentaliów. Aksjolo- 
dzy współcześni (także psycholodzy, socjolodzy, kulturoznawcy) w większości wiążą obecnie wartości (których zakres jako pojęcia i wyrazu bardzo się rozszerzył) bądź to z potrzebami ludzkimi, bądź też z przekonaniami, wyobrażeniami, uczuciami i wolą jednostek, uogólnianymi częściowo w normach kulturowych ${ }^{1}$.

Kłopot drugi polega na tym, że granice języka wartości nawet w obrębie jednej kultury nie są wyraźnie określone, są odmienne w ujęciu różnych osób, zmieniają się też w trakcie życia tych samych jednostek. Na przykład słowo brat (w znaczeniu 'członek rodziny') dla jednych z nas jest nacechowane pozytywnie, dla innych jest neutralne aksjologicznie. Podobnie jest ze słowami takimi, jak np. poezja, żotnierz, państwo, z wieloma nazwami zwierząt, miejscowości, kierunków myślowych itp. Dla części z tych nazw, a także wyrazów, które traktujemy jako niewątpliwe elementy języka wartości w danej kulturze, badania statystyczne mogą wykazać wysoki procent jakiegoś nacechowania wartościującego, ale zazwyczaj nie będzie ono dotyczyć wszystkich użyć ani też obejmować wszystkich badanych. Ten należący do pragmatyki rodzaj odmienności, ujawniający się w kontaktach językowych, może powodować spory, niechęci, poczucie obcości, czasem też tendencje do ośmieszania inaczej myślącego i oceniającego.

Trzeci rodzaj problemów, jakie miewamy z językiem wartości, wiąże się z manipulacją i kłamstwem, tj. wprowadzaniem ludzi w błąd, w wypadku manipulacji dla jakichś korzyści manipulującego, w wypadku kłamstw nie zawsze, jako że istnieja tzw. białe kłamstwa. Manipulacja i kłamstwo zazwyczaj mają na celu nadawanie wartości pozytywnych lub negatywnych niezgodnych z rzeczywistością, w kwestiach związanych z polityką - postawom, zachowaniom, sytuacjom, wydarzeniom, osobom, instytucjom, w reklamie - głównie różnego typu towarom, ale też jakimś przedsięwzięciom i sytuacjom.

Trudność ostatnia, czwarta z kolei, wiąże się z wieloznacznością i ogólnością znaczeń słownictwa aksjologicznego. Te jego cechy utrudniają porozumienie w dialogach, a także samo myślenie o wartościach, tak ważne przy budowaniu własnego systemu wartości i przy formułowaniu wszelkich ocen.

Kłopot, który wymieniłam jako pierwszy, jest dylematem „elitarnym”, dotyczy ludzi wykształconych, posługujących się słowem wartość i rozumiejących je lub przynajmniej usiłujących je jakoś rozumieć w czytanych tekstach i słyszanych wypowiedziach. Tylko dla części z nich jest to problem

${ }^{1}$ O dwudziestowiecznych pracach traktujących wartości jako transcendentalia pisał m.in. W. Stróżewski (1981: 11-95). Przegląd dwudziestowiecznych ujęć wiążących wartości z kreatywnością ludzką - zob. H. Buczyńska-Garewicz (1975a, b), także H. Joas (2009). 
dotyczący roli wartości w ich życiu wewnętrznym. Ci nieliczni stają przede wszystkim przed problemem jednej z dwóch najogólniejszych koncepcji tego, co człowiek traktuje jako swoje wartości. Musi on sobie odpowiedzieć na pytanie, czy wartościami są tylko te, które pojmuje jako absolutne, oparte na woli Boga lub natury, czy też te, które sam kreuje za pomocą swego rozumu, uczuć i woli, tj. sam decyduje o rozlicznych przedmiotach myśli, przyjmując, że są one według niego dobre lub złe. Kreuje, ewentualnie na tej drodze dochodząc do wyboru jako nadrzędnych tych wartości, które z jakichś przyczyn uznaje za absolutne lub przynajmniej obiektywne ${ }^{2}$. Wybór drugiej z przedstawionych tu koncepcji, tzn. wartości przez człowieka kreowanych, dla osób orientujących się w szerokim, różnorodnym zakresie nazw wartości, a tym samym i tego, co konceptualizujemy jako wartości, osób jednocześnie obserwujących własne, konkretne przykłady wartościowań, wydaje się najwłaściwszy ${ }^{3}$. Odpowiada on ujęciom znacznej większości współczesnych aksjologów, a zwłaszcza psychologów zajmujących się tą problematyką. Wiąże się z uznaniem autonomiczności woli człowieka, jego samodzielnego stawania przed koniecznością wyboru dobra i zła w myśli i działaniu (co nie jest też wcale sprzeczne z wiarą chrześcijańską).

Po dokonaniu takiego wyboru, zastanawiając się nad motywacjami w kreowaniu wartości, człowiek musi wybrać między upatrywaniem w tych motywacjach tylko roli własnych doświadczeń albo też bardzo ważnej roli interpretacji tych doświadczeń, co wymaga wysiłku umysłowego. Musi też wybrać koncepcję wyłącznej autokreacji bądź też kreacji w pewnej mierze intersubiektywnej, opartej na szeroko rozumianym dialogu z innymi ${ }^{4}$,

2 Anna Pawełczyńska (1992: 24) promuje taką właśnie postawę rozróżniania dwóch typów wartości. Pisze ona: „Jeżeli zakładamy, iż dobro ma charakter bezwględny [...], przyjmujemy obiektywne i niezmienne kryteria moralne. Tym samym wyodrębniamy autoteliczne wartości uniwersalne i normy z nich wynikające spośród wszelkich innych wartości i norm regulujących w sposób nietrwały partykularne interesy ludzkich społeczeństw."

${ }^{3}$ Znamienny jest wyraźny wybór tej koncepcji przez studentów lubelskich w ankiecie otwartej z 2000 roku, stanowiącej (obok ankiety z 1990 roku) podstawę obszernego opracowania pt. Język - wartości - polityka, pod red. Jerzego Bartmińskiego (2006: 113-116).

${ }^{4}$ „Powszechną cechą ludzkiej egzystencji [...] jest jej fundamentalnie dialogiczny charakter" - pisze Charles Taylor (1996: 32), powołując się na wcześniejsze wypowiedzi na ten temat G. H. Meada i M. M. Bachtina. I dodaje: „Naszą tożsamość definiujemy nieodmiennie $\mathrm{w}$ dialogu - a czasem $\mathrm{w}$ starciu - z tożsamościami, które chcieliby [...] przypisać nam nasi znaczący inni. Nawet wtedy, kiedy wyrastamy z niektórych autorytetów - niech będą to nasi rodzice - i znikają one z naszego życia, to rozmowa z nimi toczy się w naszym wnętrzu, dopóki żyjemy.” (Taylor 1996: 33). We współczesnej psychologii sprawa podmiotowości, a także wewnętrznej dialogowości człowieka budzi wielkie zainteresowanie (por. m.in. Oleś 2009, Puchalska-Wasyl 2006). Zainteresowanie podmiotowością i wewnętrzną dialogowością oraz polifonią w psychice ludzkiej przenikło też do 
a także z normami panującej kultury, jeśli one istnieją, czy też z normami jakiejś wybranej z wielu kultur składających się na współczesny, nasilony pluralizm kulturowy. Wybór (nie zawsze uświadamianej) intersubiektywności, z zachowaniem pewnych elementów indywidualnych, wydaje się bliższy prawdy. Tylko nielicznym jednostkom wydaje się, że nie poddają się w tej kwestii żadnym wpływom zewnętrznym. Natomiast zgoda na intersubiektywność wymaga zdawania sobie sprawy z niebezpieczeństwa podlegania często narzucanym stereotypom i - co gorsza - manipulacjom. Wymaga od człowieka głębszej refleksji, prowadzącej do odrzucania części narzucanych (np. przez media) wpływów i świadomego wyboru autorytetów wspomagających trudne wybory wartości uznawanych i realizowanych.

Głębszego namysłu wymaga to, w jakim stopniu interesują nas wartości istotne dla całych społeczności ludzkich, w jakim zaś ważne dla nas samych, pojęte egocentrycznie, ,interesownie".

Sprawą podmiotu jest też wybór wartości zwanych przez niektórych aksjologów mocnymi, tj. szczególnie dla danej jednostki ważnymi ${ }^{5}$, i ewentualnie przemyślane budowanie własnej hierarchii wartości, ze świadomością, że nie ma szans, by uchroniła ona przed konfliktami oraz kryzysami wartości i że zazwyczaj musi ona być w życiu w jakimś stopniu przebudowywana.

Kłopoty z rozumieniem słowa wartość nie kończą się także w momencie, kiedy zdecydujemy się na jedną z opcji wyżej omówionych. Otóż pomijając już to, że słowo wartość ma nie zawsze wyraźnie odróżnialne znaczenia ekonomiczne, matematyczne i logiczne, szczególna trudność wiąże się z jego niejednoznacznością jako terminu aksjologicznego. We współczesnej aksjologii ma ono najczęściej znaczenie bardzo ogólne: 'tego, co uważamy za dobre' (czyli 'wartości pozytywnej') i 'tego, co uważamy za złe' (czyli 'wartości negatywnej'). Natomiast także w dyskursach naukowych pojawia się dla wartości negatywnych termin antywartość, a wówczas słowo wartość obejmuje tylko to, co pozytywne. W języku potocznym wiele nieporozumień powoduje posługiwanie się słowem wartość bądź jako dotyczącym wszelkich wartości pozytywnych, bądź jako odnoszącym się tylko do tzw. wartości wyższych, inaczej zwanych duchowymi (na które składają się wartości sakralne, moralne, estetyczne i epistemiczne), z wykluczeniem witalnych i hedonistycznych. Tylko tych „wybranych” wartości dotyczy wyrażenie kryzys wartości, dość często pojawiające się w uzusie.

współczesnego językoznawstwa (por. m.in. Bartmiński red. 2006, Bartmiński 2008).

${ }^{5}$ O wartościach mocnych pisze (z aprobatą) Hans Joas (2009: 202-205), powołując się na Charlesa Taylora, który łączy je z uznawaniem ich przez dane podmioty za obiektywne i stanowiące podstawę ich poczucia tożsamości (Taylor 2001: 93). 
Używane przeze mnie wielokrotnie $\mathrm{w}$ tym tekście słowo kłopot oznacza trudności, którym trzeba jakoś stawić czoła ${ }^{6}$. Te trudności w odniesieniu do problematyki (języka) wartości mogą być większe lub mniejsze. Trudności wyboru samego znaczenia słowa wartość, również rozkładające się na skali uciążliwości, są na ogół rzadziej spotykane czy też uświadamiane niż te, które dotyczą zrozumiałości słów języka ogólnego, stanowiących nazwy wartości lub też nazwy nosicieli wartości ${ }^{7}$. A nimi właśnie chcę się zająć w dalszej części tego artykułu.

Na początek zastanówmy się nad tym, co dla nas znaczy, że coś jest dobre lub złe (inaczej mówiąc, jest wartością pozytywną lub negatywną). Obstaję przy mojej, tu w pewnym uproszczeniu podawanej definicji: „dobre jest to, co jest takie, jakie chcemy, żeby było”, „złe jest to, co jest takie, jakie nie chcemy, żeby było"8. Określenia dobry i zły stanowią podstawę wszelkich naszych wartościowań. Ich związek z naszą indywidualną wolą każe spodziewać się dużych zróżnicowań w tych wartościowaniach. I rzeczywiście tak jest: różne są nasze gusta, różne poglądy polityczne, filozoficzne i to stanowi bardzo poważną trudność w międzyludzkich kontaktach. Ale jest wiele obiektów wartościowań, które oceniamy podobnie, po prostu jako ludzie, a szczególnie jako jednostki przynależne do określonej kultury. I tak np. wszyscy cenimy zdrowie, bezpieczeństwo, pokój, a negatywnie waloryzujemy choroby, niebezpieczeństwa, wojny. Istnieją liczne kulturowe normy wartości, czasem mające tylko charakter prototypowy, ale w każdym razie pozwalające dogadywać się większości z nas co do tego, co jest dobre, a co złe.

${ }^{6}$ W Stowniku języka polskiego pod red. W. Doroszewskiego kłopot jest określony jako 'trudna lub przykra sytuacja, powodująca niepokój, zmuszająca do szczególnych zabiegów', w Innym słowniku języka polskiego PWN pod red. M. Bańki w znaczeniu 1. 'trudna sytuacja, w jakiej się ktoś znalazł', w zn. 2. 'sprawy, które nas martwią'.

${ }^{7} \mathrm{~W}$ ścisłym tego słowa znaczeniu nazwami wartości są nazwy cech, stanów, procesów lub zachowań, nazwami nosicieli wartości - ogólnie rozumiane nazwy obiektów (nazwy osób, zwierząt, instytucji, przedmiotów), które traktujemy jako wartości ze względu na właściwe im cechy, stany, procesy czy zachowania. W języku potocznym, a także w wielu pracach naukowych, wszystkie te wyrazy określa się jako nazwy wartości.

${ }^{8} \mathrm{Na}$ temat znaczenia przymiotnika dobry i jego wielojęzycznych odpowiedników toczą się od dawna dyskusje filozofów, psychologów i językoznawców. Moją pełniejszą definicję tego przymiotnika (choć jeszcze wymagającą pewnych retuszów) zawiera artykuł Horyzonty aksjolingwistyki (Puzynina 2013: 129). Wcześniejszą jej wersję skrytykował Andrzej Bogusławski (1998: 151-152), który później (Bogusławski 2011: 204-210) raz jeszcze zajął się opisem znaczenia angielskiego good. Anna Wierzbicka pierwotnie (1971: 235-236) definiowała dobrego w sposób podobny do mojej uproszczonej wersji, później, poczynając od 1989a, uznała za właściwą, promowaną przez E. G. Moore’a, niedefiniowalność tego ważnego, uniwersalnego pojęcia (z czym trudno się zgodzić językoznawcom zajmującym się aksjolingwistyką). 
Jednakże ilekroć na daną wartościowaną cechę, czynność czy przedmiot składa się wiele elementów, zaczynają się nowe kłopoty. Na przykład wszyscy oceniamy pozytywnie ludzką dobroć - tu mamy do czynienia z normą, przynajmniej prototypową. Ale zastanówmy się, co to znaczy być dobrym człowiekiem, jak rozumiemy tę na ogół wysoko ocenianą dobroć, o której Cyprian Norwid w wierszu Do Bronisława Z. powiedział:

Z rzeczy świata tego zostaną tylko dwie,

Dwie tylko: poezja i dobroć... i więcej nic...

Umiejętność nawet bez dwóch onych zblednie jak papier.

W słownikach języka polskiego znajdujemy różne opisy znaczenia przymiotnika dobry. Czytamy, że „ktoś, kto jest dobry, jest życzliwy dla innych ludzi i gotów im pomagać" (ISJP), Bogusław Dunaj do znaczenia dobrego człowieka włącza 'łagodność, wrażliwość i serdeczność', a jako odrębne znaczenie tego przymiotnika traktuje 'przestrzeganie zasad moralnych, prawość i szlachetność' (SWJP). Witold Doroszewski prócz 'życzliwości, skłonności do pomagania, łagodności i serdeczności' wymienia jako elementy dobroci 'poczciwość i przyjazność'. Część wymienionych przez słownikarzy elementów treści dobroci nie należy, jak się wydaje, do jej cech koniecznych. Mówimy nieraz o kimś, że jest szorstki, oschty, a nawet agresywny w sposobie bycia, wcale nie łagodny ani serdeczny, a że przecież to jednocześnie dobry człowiek. Nie zawsze ludzie, których określamy jako dobrych, zasługują też na miano prawych czy szlachetnych, skoro do prawości włączamy co najmniej uczciwość, a do szlachetności wspaniałomyślność i wielkoduszność. Możemy powiedzieć, że Kowalski, choć to niewątpliwie złodziejaszek, jest jednocześnie dobrym człowiekiem, skłonnym pomagać ludziom w potrzebie. Wszystkie wymienione tu cechy „niekonieczne” dobrego człowieka stanowia silniej lub słabiej skonwencjonalizowane konotacje dobroci. Cechy inwariantne człowieka dobrego to - w moim pojęciu - tylko 'życzliwy stosunek do ludzi oraz gotowość pomocy i takiej pomocy jej potrzebującym w praktyce świadczenie'. Jednakże jak trudno ustalić nawet inwariant znaczeniowy dobroci, o tym świadczy opinia Renaty Grzegorczykowej, która $\mathrm{w}$ artykule pt. Jeszcze $w$ sprawie rozumienia dobra $i$ dobroci uznała, że życzliwość (także, jak się okazuje, różnie rozumiana) jest słabszym, bliskim tzw. „pobożnym życzeniom” bliskoznacznikiem dobroci, a nie składnikiem jej znaczenia i zdecydowanie ją usunęła z określenia dobrego człowieka. Z kolei „świadczoną pomoc" uznała za niekonieczną jego cechę, a opierając się na określeniu Korczaka ${ }^{9}$ : „Dobry to taki, który ma wyobraźnię, rozumie, jak jest

\footnotetext{
${ }^{9}$ Cytaty z pism Korczaka autorka podaje za szkicem O dobroci Tadeusza Żychiewicza, bez danych bibliograficznych.
} 
drugiemu człowiekowi, umie odczuć, co drugi czuje”, napisała: „Dobroć jest więc funkcją wyobraźni, a wyobraźnia warunkiem dobroci". Dobroć w tym ujęciu została sprowadzona do empatii. Wydaje się też, że wyobraźnia nie zawsze jest potrzebna, często i współodczuwanie, i pomoc nie muszą być nią wspomagane - potrzeby pomocy bywają bardzo oczywiste. Poza tym wyobraźnia, podobnie jak rozum i uczucie, to czynniki ważne dla powstawania aktów dobroci, ale nie jej cechy składowe.

Przymiotnikiem dobry w odniesieniu do człowieka zajął się również Leszek Kołakowski (2010: 240-247), a w dyskusji z nim i między sobą Marian Przełęcki (2011: 85-92 i 101-105), Anna Brożek (2011: 92-97) i Jacek Jadacki (2011: 97-101 i 105-107). Według prof. Kołakowskiego dobrymi można nazwać ludzi ,zawsze życzliwych i pomocnych dla bliźnich, wolnych od mściwości, zawiści i nienawiści, nigdy niemówiących i nieczyniących niczego, co by mogło innych upokorzyć" (Kołakowski 2010: 243). Prof. Przełęcki w ślad za Tadeuszem Kotarbińskim dobre moralnie zachowania człowieka wiąże z „obroną drugiego człowieka przed cierpieniem, w szczególności - przed grożącym mu nieszczęściem" (Przełęcki 2010: 86). Dr Brożek dobre czyny ludzkie łączy z świadczeniem dobra witalnego, ,przy czym dobro witalne to życie, zdrowie lub (szeroko rozumiane) mienie" (Brożek 2011: 95). A prof. Jadacki sądzi, że ci sami ludzie „bywają dobrzy i bywają źli”, toteż „nie spieszmy się z potępianiem, ale i z ... pochwałami”, tym bardziej że „niełatwo jest czasem sprawiedliwie ocenić - zwłaszcza pod względem moralnym czyjeś postępowanie" (Jadacki 2010: 97, 107) ${ }^{10}$. Ta dyskusja ukazuje w sposób dobitny różnice w pojmowaniu ludzkiej dobroci.

Jak widać, trudno jest ustalić wyraźną normę znaczeniową tego słowa; podobnie byłoby np. z życzliwościa, szlachetnościa, prawościa, wielkodusznościa, honorem, a wśród określeń negatywnych człowieka, np. z podłościa, hańba czy też potocznym draństwem ${ }^{11}$. Użycia przytoczonych tu przykładowo wyrazów są bardzo zależne od konkretnych sytuacji, które one w jakimś momencie współopisują, a indywidualne uogólnienia ich znaczeń zależą

${ }^{10}$ Dyskusja, o której tu była mowa, dotyczyła nie tylko znaczenia przymiotnika dobry jako określenia człowieka, ale też tego, czy - jak sądził Leszek Kołakowski - „w każdym człowieku jest coś dobrego", a przynajmniej: „każdy z nas nosi w sobie zdolność do dobra” (Kołakowski 2010: 243-244).

${ }^{11}$ Semantyka podłości została opisana przez Radosława Pawelca w pracy poświęconej antywartościom (Pawelec 2013). Na podstawie użyć notowanych w Narodowym Korpusie Języka Polskiego Pawelec ukazuje szereg odstępstw od znaczenia prototypowego przymiotnika podty, wiązanego zazwyczaj z postępowaniem w bardzo wysokim stopniu nieetycznym. Podobnie w jego opisie znaczenia hańby pojawiają się takie przykłady odstępstw od jej moralnego znaczenia, jak np. nazwanie hańba niezabezpieczenia ruchomym dachem nowego stadionu warszawskiego przed ulewą w czasie ważnego meczu. 
od pamięci tych sytuacji, a także od świata wewnętrznego osób, które te sytuacje tak czy inaczej interpretują. Wszystko to powoduje, że bardzo często nadawca i odbiorca wypowiedzi zawierających m.in. te (przykładowe) wyrazy nie mają tego samego na myśli.

Ale gdyby nawet pozostać przy przytoczonej wyżej propozycji cech koniecznych dobroci, to i w ich zakresie pojawią się dalsze kłopoty, m.in. związane z ogólnością ich znaczeń i rozmaitością sytuacji, których one mogą dotyczyć. I tak np. trzeba sobie zadać pytanie, czy człowieka dobrego ma obowiązywać - a jeżeli tak, to jak się ma wyrażać - życzliwość wobec ludzi zdecydowanie złych. Tu już treść przymiotnika dobry nie pomoże, trzeba samemu ją doprecyzowywać zgodnie z etyką, którą się uznaje za swoją. Podobnie jest z wymogiem pomocy innym. Po pierwsze - pomoc komu przede wszystkim? Bo potrzebujących jest bardzo wielu. W jakim sensie słabym? I czy tylko znanym, jakoś bliskim, czy też właśnie nieznanym (a tak często głodującym), nawet z ryzykiem trafienia na oszustwa? I do jakich granic powinna sięgać ofiarność dobrego człowieka, czy to w sferze finansowej, czy poświęcania własnego czasu? Jak widać, konkretyzacje bycia dobrym człowiekiem zależą od poszczególnych ludzi, ich możliwości, ale też kierunków ich refleksji - i intencji, które mogą mieć też czasem więcej związków z piarem niż z dobrocia. Od indywidualnego rozumienia dobroci zależą też oceny tego, czy lub w jakim stopniu inne osoby zasługują na miano dobrych ludzi $i^{12}$.

Treść takich słów, jak solidarność, wierność, postuszensstwo obok problemów z ogólnością znaczeń, brakiem sprecyzowania tego, na czym solidarność czy wierność mają polegać, sprawia też inne kłopoty, zarówno w kierowaniu własnym postępowaniem, jak i w ocenie innych osób. Są one wartościami instrumentalnymi: solidarnym, wiernym, posłusznym można być wobec różnych, pozytywnie lub negatywnie ocenianych ludzi, grup ludzkich, instytucji (wiernym także bardzo różnym, pozytywnym lub negatywnym zasadom, ideałom). Także np. odwagę można wykazywać w działaniach dobrych i złych - w obronie kraju, ale też w napadach na banki. Zwykliśmy wszystkie wymienione słowa wartościować pozytywnie, tymczasem nie zawsze one na to zasługują, w zależności od tego, komu i czemu służą, mogą też być przejawem słabości charakteru, głupoty lub przekonania, że jakiś wątpliwy cel, uznany za dobry czy też w jakimś sensie korzystny, usprawiedliwia działanie na jego rzecz. Z drugiej strony nazwy wartości, takie jak solidarność, wierność, odpowiedzialność, mogą prowokować do niesprawie-

\footnotetext{
${ }^{12}$ Kłopotów tego typu, jak wyżej wymienione, nie sprawiają nazwy tych wartości negatywnych, które odnoszą się do bardzo konkretnych, niewątpliwie negatywnie ocenianych w naszej kulturze zachowań, tj. antywartości, takich jak obżarstwo, oszczerstwo, mord, a także takich uczuć i skłonności, jak nienawiść, zazdrość, obrażalstwo.
} 
dliwych ocen negatywnych wobec tych, którzy w rzeczywistości ze względu na dojrzałą modyfikację poglądów zmieniają np. ugrupowanie, wobec którego byli poprzednio solidarni, którzy - idąc za głosem sumienia - zmieniają punkt odniesienia swojej wierności czy też odpowiedzialności.

Trzeba tė̇ pamiętać, że na wartościowanie takich nazw, jak komunizm, socjalizm, kapitalizm, liberalizm, chrześcijaństwo składają się oceny wielu elementów należących do ich teoretycznych programów, a także do ich realizacji. Często aprobujemy tylko część z ich składników, sami decydujemy, co uważamy za istotne, co za mniej ważne ${ }^{13}$. Poglądy tych ocen dotyczące zmieniają się niejednokrotnie pod wpływem nowych doświadczeń, nowej wiedzy, także nowych autorytetów. Zarówno zmieniające się oceny uznanych za ważne, pozytywnych bądź negatywnych elementów programów, jak tė̇ oceny rozbieżności między programami i ich realizacjami, mogą mieć istotny wpływ na zmiany systemów wartości poszczególnych osób pierwotnie związanych z którąś z tych ideologii i systemów społeczno-politycznych ${ }^{14}$. Oczywiście bywają też zmiany związane z dezaktualizacją niektórych programów (np. po 1989 roku komunizmu w Europie) i/lub zmiany (po części?) pozorowane, koniunkturalne, dokonywane ze względu na jakieś spodziewane korzyści.

Ostatnie lata dziejów politycznych naszego kraju są przykładem kłopotów i zawirowań w naszych partiach politycznych. Polegają one na odchodzeniu członków z którejś partii ze względu na jakieś ich obiekcje wobec poglądów i wartości przez tę partię uznawanych lub realizowanych ${ }^{15}$, a przy tym wysuwanie przez władze tej partii postulatu rezygnacji z własnej tożsamości poszczególnych członków na rzecz tożsamości grupowej ${ }^{16}$.

${ }^{13}$ Wspomniana w przypisie 3. praca pod red. J. Bartmińskiego, przy pewnych swoich wadach, o których nie miejsce, by tu mówić, ma istotną zaletę: ukazuje w przeprowadzonych ankietach otwartych wielorakość elementów znaczeniowych przypisywanych przez osoby ankietowane badanym wyrazom, po części często powtarzających się, po części jednak odbiegających od zawartości znaczeń prototypowych. Niestety, opracowanie obejmuje tylko określenia powtarzające się co najmniej cztery razy, rzadsze (a stanowiące od kilkunastu do czterdziestu kilku procent wszystkich zanotowanych) są dostępne tylko w archiwum Pracowni (Archiwum Etnolingwistyczne). To wśród nich kryją się najciekawsze odstępstwa od norm kulturowych.

${ }^{14}$ Przykłady takich licznych zmian za czasów PRL-u odnotowują książki, takie jak Pułapki zaangażowania M. Hirszowicz (2001), Dzienniki M. Jastruna (2002), Jak wierza uczeni M. Bajer (2010), Rachunek pamięci F. Bieńkowskiej, H. Boguszewskiej i in. (2012).

${ }^{15} \mathrm{Na}$ przykład PIS-owskiej wersji patriotyzmu, PO-wskiej centrowości czy też SLD-owskiej lewicowości. To prowadzi czasem do zmian przynależności partyjnej (bywa, że dla zachowania korzyści materialnych).

${ }^{16}$ Stanowi to dla członków partii poważny kłopot dotyczący istotnego przecież elementu moralności jednostkowej. 
Nie zawsze zmiany ideowe traktujemy jako kłopoty, czasem jako dojście do hierarchii wartości, które pojmujemy jako z jakichś względów lepsze, oparte na prawdzie, mające głębszy czy też pragmatycznie większy według nas sens. Oczywiście oceny przeżywających kryzysy wartości i zmiany orientacji nie pokrywają się z ocenami zewnętrznymi, często powierzchownymi, czasem krzywdzącymi, czasem odwrotnie - zbyt usprawiedliwiającymi czy wręcz pochlebnymi.

Wszystko, o czym mówiłam dotychczas, to w zasadzie rzeczy znane, nic nowego. Myślę jednak, że nie są one dostatecznie uświadamiane jako wymagające refleksji kłopoty z problematyką wartości, a także z językiem wartości, który jest przecież narzędziem naszego myślenia, a pośrednio jednym z bodźców wywołujących przeżycia emocjonalne. Nazwy wartości nie są na ogół pojmowane jako elementy życia wewnętrznego, kierujące w dużej mierze postawami i działaniami człowieka, a tym samym warte pilnej uwagi. A przecież np. intelektualiści, tacy jak bohaterowie książki z wywiadami Magdaleny Bajer Jak wierza uczeni, niejednokrotnie wspominają swoje „późne dojrzewanie”, późne znajdowanie wcześniej niedostrzeganych wartości, które nadają egzystencjalny sens ich życiu. Część z nich opowiada też o okresach życia, w których ulegali wpływom pięknych słów propagandy komunistycznej i o tym, jak się z tych wpływów wyzwalali. Ta książka i liczne inne wspomnieniowe publikacje ${ }^{17}$ zawierają materiały potwierdzające rolę, jaką odgrywała peerelowska propaganda w kształtowaniu hierarchii wartości zwłaszcza ludzi młodych, niedoświadczonych, poświadcza ich nierzadkie uleganie manipulacji językowej - a z drugiej strony znaczenie właściwej interpretacji doświadczeń oraz ważności dobrych wpływów „ludzi drogowskazów", jak ich nazywa prof. Andrzej Zoll (Bajer 2010: 277), np. takich nauczycieli, jak wspominany i przez prof. Włodzimierza Boleckiego (Bajer 2010: 44), i przez prof. Andrzeja Górskiego (Bajer 2010: 129) Ireneusz Gugulski ${ }^{18}$, a także ważnych lektur, broniących kultury opartej na podstawowych wartościach duchowych ${ }^{19}$. „Pokolenie żyjących jest wielkie nie tylko wielkością tego, czego zamierza dokonać, lecz również wielkością tych, których dzieło kontynuuje" - pisał ks. Józef Tischner (1982: 461).

${ }^{17}$ Zob. przypis 14 .

18 Był to znakomity polonista pracujący (z wymuszonymi przerwami) od 1959 do 1990 roku (tj. do śmierci).

${ }^{19}$ W Niemczech w 1995 roku ukazała się książka Das Buch der Werte. Wider die Orientierungslosigkeit in unserer Zeit (pod red. Friedricha Schorlemmera). Zawiera ona wielką liczbę różnego rodzaju tekstów (od starożytności po współczesność), uporządkowanych w piętnastu rozdziałach, poświadczających przeżywanie i/lub omawianie istotnych dla człowieka i społeczeństwa wartości przez postaci biblijne, poetów, pisarzy, myślicieli, uczonych. Byłoby dobrze, gdyby przekład tej książki mógł się ukazać w Polsce. 
Mówię o takim przesłaniu tych wypowiedzi, ponieważ wydaje mi się ono bardzo ważne w naszej obecnej rzeczywistości ${ }^{20}$. Dziś inny, ale nie mniej rujnujący osobowości, jest wpływ na młode pokolenie kultury ponowoczesności, zarówno w jej wersji elitarnej, jak i popularnej. Przeciwstawiać się temu można, starając się wpływać na kształtowanie się norm kulturowych. Tu również w książce Jak wierza uczeni znalazłam ważne wypowiedzi prof. Macieja Żylicza (Bajer 2010: 321-324) i prof. Karola Życzkowskiego (Bajer 2010: 302-304) na temat obowiązku włączania się ludzi nauki w korygowanie i ulepszanie imaginarium społecznego ${ }^{21}$.

Sądzę, że dla sprawy ulepszania naszego imaginarium rzeczą niezwykle ważną jest skierowywanie refleksji wszystkich pokoleń na koncepcję człowieka. O niej, jako bardzo istotnej, wypowiadał się też w swoim wywiadzie prof. Włodzimierz Bolecki; oto jego słowa:

Skupiam się na tym, co jest najbliższe każdemu humaniście, na pytaniu: kim jest człowiek jako istota moralna, jako cząstka tego cudu, który na ziemi nazywamy życiem, a zarazem jako twórca kultury. (Bajer 2010: 56)

Ostatnie słowa tej wypowiedzi wydają mi się bardzo ważne jako argument przemawiający za niezwykłością człowieka: jeśli ktoś nie wierzy w jego wielkie możliwości, niech spojrzy na imponujące świadectwa jego działalności w postaci ogólnoludzkiej kultury: muzyki, sztuk plastycznych, literatury, architektury, nauki, świadectw bohaterstwa i ofiarności społecznej.

Jednakże poziom intelektualny i moralny poszczególnych jednostek jest bardzo różny. Wielu uczonych od lat zastanawia się nad możliwościami ulepszania człowieka. Rozpatrywane są trzy możliwości osiągania dobrych wyników w tych usiłowaniach: inżynieria genetyczna, propagowana przez S. Haw-

20 „Człowiekiem drogowskazem” w Polsce pozostał w dużym stopniu, także dla młodych, do chwili obecnej, Jan Paweł II, teraz staje się nim również papież Franciszek.

${ }^{21}$ Imaginarium społeczne to termin współczesnych nauk społecznych, któremu wiele uwagi poświęca Ch. Taylor (2010). Pojęcie imaginarium wywodzi się ze znanej pracy B. Andersona Wspólnoty wyobrażone (1997). Charles Taylor określa je jako „sposoby, w jakie ludzie wyobrażają sobie swoją społeczną egzystencję, jak przystosowują się do innych, jak toczą się sprawy między nimi i bliźnimi; to także oczekiwania [...] oraz głębsze normatywne koncepcje i obrazy, leżące u ich podstaw (Taylor 2010: 37). Te „głębsze normatywne koncepcje" wiążą się z ,uwewnętrznionym rozumieniem przestrzeni społecznej”, a jego istotną częścią jest „,sens porządku moralnego”. Ów porządek z kolei opiera się na etyce wolności jednostek i wzajemnych korzyściach wszystkich obywateli, wolności, korzyściach, których „zabezpieczenie wiąże się z ćwiczeniem cnoty” (Taylor 2010: 34).Warto zauważyć, że ważność wzajemnych korzyści w życiu wspólnot była zauważana od bardzo dawna. Wzajemność jako podstawa struktury społecznej to tytuł rozdziału w Normach moralnych Marii Ossowskiej (1970: 196), która przywołuje wcześniejsze wypowiedzi na ten temat Mandeville'a, Hobesa i Malinowskiego, a także opisywane przez tego ostatniego obrzędy wzajemnego obdarowywania się plemienia Trobriandów. 
kinga, kulturyzacja, popierana m.in. przez Goethego, Marksa i behawiorystę Skinnera, oraz samorozwój oparty na aktywności psychicznej jednostki. Ta ostatnia droga, za którą opowiada się m.in. prof. Józef Kozielecki (1999: 124-127), wiąże się niewątpliwie z „moralnością wyższego rzędu”, opartą, jak o tym pisze Maria Jarymowicz, ,,na rozwoju zdolności rozumowania moralnego - pochodnych rozwoju intelektu i narzędzi rozumienia złożoności świata" (1999: 191). Do tych narzędzi należy niewątpliwie m.in. aksjologia i powiązana z nią aksjolingwistyka.

Polskie imaginarium społeczne uległo wyraźnym podziałom. Katarzyna Kłosińska w swojej pracy pt. Etyczny i pragmatyczny. Polskie dyskursy polityczne po 1989 roku (2012) pisze o dwóch takich właśnie, jak w tytule jej książki, jego częściach. Wydaje się, że są i dalsze podziały: romantyków na ostro radykalnych i usposobionych pokojowo, pragmatyków na uspołecznionych i egocentrycznych - to ostatnie imaginarium, zainteresowane głównie wartościami hedonistycznymi, jest największym zagrożeniem dla kultury polskiej. Trudno jest mu przeciwdziałać, ponieważ znajduje ono oparcie w telewizji, Internecie, kolorowych mediach, wszędobylskiej reklamie, a w edukacji szkolnej i domowej na ogół brak silnego, dobrze pomyślanego przekazu aksjologicznego, brak też obrony sumienia, podejmowanej przez przedstawicieli wyznań religijnych, a także niektórych uczonych ${ }^{22}$. Radość budzą coraz liczniejsze inicjatywy obywatelskie takie przeciwdziałania wobec kultury hedonizmu podejmujące.

\section{Literatura}

Bajer Magdalena, 2010, Jak wierza uczeni. Rozmowy z profesorami, Warszawa: Fronda. Bartmiński Jerzy, Niebrzegowska-Bartmińska Stanisława, Nycz Ryszard (red.), 2004, Punkt widzenia w języku i w kulturze, Lublin: Wydawnictwo UMCS.

Bartmiński Jerzy (red.), 2006, Język - wartości - polityka. Zmiany rozumienia nazw wartości w okresie transformacji ustrojowej w Polsce. Raport z badań empirycznych, Lublin: Wydawnictwo UMCS.

Bartmiński Jerzy, 2008, Polifoniczność tekstu czy podmiotu? Podmiot w dialogu z samym soba, [w:] Podmiot w języku i kulturze, red. Jerzy Bartmiński, Anna Pajdzińska, Lublin: Wydawnictwo UMCS, s. 161-183.

Bauman Zygmunt, 2012, Etyka ponowoczesna, tłum. Janina Bauman, Joanna Tokarska-Bakir, Warszawa: Wydawnictwo Aletheia.

Bieńkowska Flora, Boguszewska Helena, Flaszen Ludwik i in., 2013, Rachunek pamięci, Warszawa: Wydawnictwo Więź.

${ }^{22}$ Należy do nich m.in. Zygmunt Bauman, podejmujący w sposób zdecydowany taką obronę w Etyce ponowoczesnej (2012). 
Bogusławski Andrzej, 1998, On "good" and "bad", [w:] Science as linguistic activity, linguistics as scientific activity, Warszawa: Katedra Lingwistyki Formalnej UW, s. $145-171$.

Bogusławski Andrzej, 2011, Reflections on Wierzbicka's explications and related essays, Warszawa: BEL Studio Sp. z o.o., s. 173-210.

Brożek Anna, 2011, Uwagi o pojęciu dobra, [w:] Anna Brożek, Jacek Jadacki, Marian Przełęcki, W poszukiwaniu najwyższych wartości. Rozmowy międzypokoleniowe, Warszawa: Wydawnictwo Naukowe „Semper”, s. 92-97.

Buczyńska-Garewicz Hanna, 1975a, Uczucie i rozum w świecie wartości, Wrocław: Ossolineum.

Buczyńska-Garewicz Hanna, 1975b, Znak, znaczenie, wartość. Szkice o filozofii amerykańskiej, Warszawa: Książka i Wiedza.

Hirszowicz Maria, 2001, Pułapki zaangażowania. Intelektualiści w służbie komunizmu, Warszawa: Wydawnictwo Scholar.

ISJP - Inny słownik języka polskiego, red. Mirosław Bańko, Warszawa 2000.

Jadacki Jacek, 2011, Bywaja ludzie, którzy bywaja dobrzy i bywaja źli, [w:] Anna Brożek, Jacek Jadacki, Marian Przełęcki, W poszukiwaniu najwyższych wartości. Rozmowy międzypokoleniowe, Warszawa: Wydawnictwo Naukowe „Semper”, s. $97-101$.

Jarymowicz Maria, 1999, Poznać siebie - zrozumieć innych, [w:] Humanistyka przełomu wieków, red. Józef Kozielecki, Warszawa: Wydawnictwo Akademickie „Żak”, s. $179-197$.

Jastrun Mieczysław, 2002, Dziennik, Kraków: Wydawnictwo Literackie.

Joas Hans, 2009, Powstawanie wartości, tłum. Michał Kaczmarczyk, Warszawa: Oficyna Naukowa.

Kłosińska Katarzyna, 2012, Etyczny i pragmatyczny. Polskie dyskursy polityczne po 1989, Warszawa: Narodowe Centrum Kultury.

Kołakowski Leszek, 2010, Czy Pan Bóg jest szczęśliwy i inne pytania, Kraków: Społeczny Instytut Wydawniczy „Znak".

Kozielecki Józef, 1999, Zaduma nad możliwościa ulepszania człowieka, [w:] Humanistyka przełomu wieków, red. Józef Kozielecki, Warszawa: Wydawnictwo Akademickie ,Żak", s. 115-127.

Oleś Piotr, 2009, Dialogowość wewnętrzna jako właściwość człowieka, [w:] Nowe idee w psychologii, red. Józef Kozielecki, Gdańsk: Gdańskie Wydawnictwo Psychologiczne, s. 216-235.

Ossowska Maria, 1970, Normy moralne. Próba systematyzacji, Warszawa: PWN.

Pawelec Radosław, 2013, Ciemne zwierciadło. Semantyka antywartości, Warszawa.

Pawełczyńska Anna, 1992, Relatywizm moralny a wartości bezwzględne, [w:] Wartości i ich przemiany, red. Anna Pawełczyńska, Warszawa: Wydawnictwo Archidiecezji Warszawskiej, s. 12-29.

Przełęcki Marian, 2011, Czy ludzie sa dobrzy?, [w:] Anna Brożek, Jacek Jadacki, Marian Przełęcki, $W$ poszukiwaniu najwyższych wartości. Rozmowy międzypokoleniowe, Warszawa: Wydawnictwo Naukowe „Semper”, s. 85-92.

Puchalska-Wasyl Małgorzata, 2006, Nasze wewnętrzne dialogi. O dialogowości jako sposobie funkcjonowania człowieka, Wrocław: Wydawnictwo Uniwersytetu Wrocławskiego.

Puzynina Jadwiga, 2013, Horyzonty aksjolingwistyki, [w:] Wartości i wartościowanie w perspektywie językoznawstwa, Kraków: Wydawnictwo PAU, s. 123-139.

Schorlemmer Friedrich (red.), 1995, Das Buch der Werte. Wider die Orientierungslosigkeit in unserer Zeit, Stuttgart: Verlagshaus Stuttgart GmbH. 
Stróżewski Władysław, 1981, Transcendentalia i wartości, [w:] Istnienie i wartość, Kraków: Społeczny Instytut Wydawniczy „Znak”, s. 11-96.

SWJP - Stownik wspótczesnego języka polskiego red. Bugusław Dunaj, Warszawa 1996.

Taylor Charles, 1996, Etyka autentyczności, tłum. Andrzej Pawelec, Kraków: Społeczny Instytut Wydawniczy ,Znak”.

Taylor Charles, 2001, Źródła podmiotowości. Narodziny tożsamości nowoczesnej, tłum. Marcin Gruszczyński, oprac. Tadeusz Gadacz, wstęp Agata Bielik-Robson, Warszawa: Wydawnictwo Naukowe PWN.

Taylor Charles, 2010, Nowoczesne imaginaria społeczne, tłum. Adam Puchejda, Karolina Szymaniak, Kraków: Społeczny Instytut Wydawniczy „Znak”.

Tischner Józef, 1982, Myślenie według wartości, Kraków: Społeczny Instytut Wydawniczy „Znak”.

Wierzbicka Anna, 1989, Semantic primitives and lexical universals, „Quaderni di Semantica", nr 1, s. 103-121.

Wierzbicka Anna, 1971, Kocha, lubi, szanuje. Medytacje semantyczne, Warszawa: Wiedza Powszechna.

\section{Problems With Value terms (AND Values)}

The article discusses difficulties with understanding the language of values and with using it in communication: it concerns the very term wartość 'value' and numerous value terms with general meanings and many component semantic features. The problem is discussed in a broader context of the adjective dobry 'good' when applied to persons. Problems with values and value terms include also frequent modifications of value hierarchies of many people. This results in serious communicative disturbances and inadequate assessments of phenomena and events.

The final part of the article deals with the kinds of influence on ethically rational formation of the identity of the young generation, important for social and generally humanistic reasons.

KEY WORDS: language of values, value terms, communication, identity, dobry 'good' 